\title{
Dekonštrukcia liberálnej demokracie 21. storočia ako politickej formy neskorého kapitalizmu
}

\author{
Peter Daubner \\ Filozofický ústav Slovenskej akadémie vied, SK
}

\begin{abstract}
DAUBNER, P.: Deconstruction of the $21^{\text {st }}$ Century Liberal Democracy as a Political Form of Late Capitalism.

Philosophica Critica, vol. 5, 2019, no. 2, ISSN 1339-8970, pp. 46-56

The contribution presents a philosophical reflection of the notion of democracy as well as the contemporary western type of liberal democracy as a political form of late capitalism, which is ontologically and geographically ubiquitous as an established economic system. The contribution analyzes the crisis of liberal democracy, working within the framework of late capitalism through the perspective of post-Marxist philosophy, and looks for potential parallels between Plato and Marx in the understanding of democracy.
\end{abstract}

Key words: Liberal Democracy - Late Capitalism - Politeia - Plato Marx

\section{Úvod}

L'udia takmer všetkých politických presvedčení vyznávajú akési nadšenie k demokracii, ale majú tendenciu si pod týmto termínom predstavovat' rôzne záležitosti. P. Kulašik konštatuje, že pojem demokracia je v politologických a politicko-filozofických diskusiách t’ažko definovatel’ný a značne nevd’ačný termín, pretože jeho význam (obsah) je natol'ko vážny, že mu hrozí strata akýchkol'vek hlbších súvislostí (Kulašik 2007). „Demokracia sama o sebe predstavuje mnohovrstvovú tému, zložitý teoretický problém, náročný spoločenský projekt a polyvalentný termín, ktorý môže znamenat’ mnoho a zároveň nič“ (Sekerák 2013, 39). Demokracia je v súčasnosti pod útokom, zároveň pritom nie je jasné, čím vlastne je (Slačálek 2012). Etymologicky je však pojem demokracia jednoznačný: pochádza 
z gréckeho démos (l'ud) a kratein (vládnut'). Demokraciu môžeme teda preložit' ako l'udovládu (Kulašik 2007).

Klasicky je teda demokracia definovaná ako vláda množstva (l’udu) a je v protiklade k vláde niekol'kých, a to bud' vláde aristokratickej alebo oligarchickej, a tiež v protiklade k vláde jedného, a to bud' vláde monarchickej alebo tyranskej (Znoj 2014). E. Todd konštatuje, že jednou z prvých definícií demokracie bola tá Aristotelova, ktorá bola dokonale moderná v tom, že sa zakladala na rovnováhe princípov „slobody“ (eleutheria) a „rovnosti“ (isonomia) (Todd 2007). Je však súčasná forma liberálnej demokracie skutočne založená na princípoch rovnosti a slobody? Súčasnú liberálnu demokraciu, ktorá sa etablovala počas 20 . storočia, možno vo všeobecnosti chápat' ako formu reprezentatívnej (zastupitel'skej) demokracie, v ktorej sú vo vol'bách volení zástupcovia l'udu obmedzovaní ústavou tak, že ústava chráni individuálne slobody všetkých občanov. V tejto stati budeme analyzovat' liberálnu demokraciu (a jej krízu) alternatívnym spôsobom, optikou jej súčasného pôsobenia v rámcoch neskorého kapitalizmu ${ }^{1}$.

\section{Kríza liberálnej demokracie}

V roku 1989, v tom annus mirabilis, akoby dejiny stanovili ideologického vít’aza, liberálnu demokraciu (Krastev 2017). Na konci osemdesiatych rokov sa neoliberálny kapitalizmus, resp. neoliberalizmus stal tzv. „uniformným myslením" (pensée unique) v strede politického spektra, a staré politické otázky a spory sa začali pokladat' za definitívne vyriešené (Streeck 2017). A v 90. rokoch sa skutočne zdalo, že spolužitie kapitalizmu a demokracie dospelo do štádia, ked' sme sa už diskusiami o konkurencieschopnej alternatíve nemuseli vôbec zaoberat' (Arnason 2012). A to aj vzhl'adom na skutočnost', že už dlho pred rokom 1989 bolo zrejmé, že štátny socializmus v krajinách východného bloku nepredstavuje životaschopnú a prít’ǎlivú podobu socializmu (Bíba 2014a). V minulosti sa teda naozaj mohlo zdat', že západná liberálna demokracia triumfuje nad svojim zlým „dvojčatom“ (totalitarizmus in stricto sensu), avšak situácia sa zmenila v okamihu, ked' sa po niekol'kých desat'ročiach povojnovej prosperity slubujúcej budúcnost' neobmedzeného pokroku začali rozkladat' štrukturálne podmienky, ktoré spôsobili, že organické prepojenie medzi ústavnými liberálnymi slobodami a slobodným (liberalizovaným a neregulovaným) podnikaním na pôde sociálno-trhovej ekonomiky a inštitucionalizovaného sociálneho welfare štátu (fordisticko-keynesiánsky kompromis) sa stalo neudržatel'ným (Bensaid 2011).

K vymedzeniu neskorého kapitalizmu pozri Jameson (2009). 
Súčasná kríza, v ktorej sa ludstvo ocitlo, totiž nie je iba krízou ekonomickou, ale aj krízou liberálnej demokracie (Pehe 2012). Kríza liberálnej demokracie predstavuje indikátor obnovy triedneho konfliktu. Túto skutočnost' si uvedomuje najmä trieda bohatých, ktorá používa stigmatizujúcu, agresívnu a triednu politiku (Slačálek 2012). V podstate takmer všetky prognózované riziká spojené s procesom globalizácie sa v posledných rokoch stali skutočnost'ou - napr. medzinárodný terorizmus, klimatické zmeny, finančná kríza a najmä migračné vlny; liberálna demokracia však na tieto riziká nebola politicky pripravená (Geiselberger 2017).

Kríza liberálnej demokracie sa objavuje v ére, ktorá je charakteristická mocenskou asymetriou medzi tými, ktorí maximalizujú zisk z kapitálu, a tými, ktorí sa živia svojou prácou (Barša 2012). V skratke, na jednej strane rastie bohatstvo a na strane druhej „závislost' a núdza“ triedy odkázanej na námezdnú prácu (Znoj 2014). Je snád’ takmer nemožné prehliadat' symptómy krízy liberálnej demokracie: výrazný pokles volebnej participácie, národné vlády tvrdošijne presadzujúce neoliberálne reformy, a to napriek vytrvalému odporu verejnosti, demokratický deficit, podreprezentácia celých segmentov spoločnosti, demontáž sociálneho štátu, a v neposlednom rade tiež volebné úspechy nového populizmu autoritárskej pravice a presakovanie ich slovníka a tém do verejného diskurzu (Znoj, Bíba, Vargovčíková 2014).

\section{Dekonštrukcia liberálnej demokracie}

Nie je dnes preto ústrednou otázkou politickej filozofie to, či sa nestávame svedkami toho, ako sa čast' sveta postupne vzdáva liberálnej demokracie a nahrádza ju akýmisi obskúrnymi populisticko-autoritárskymi režimami? A. Appadurai tvrdí, že skutočnou hrozbou pre planétu sú noví populisti autoritárskeho strihu presadzujúci politickú zmes neoliberalizmu, kultúrneho šovinizmu a protiimigračných nálad založených na frustrácii väčšinovej spoločnosti (Appadurai 2017). To, čomu dnes musíme v liberálnych demokraciách čelit', je vzostup demagógov, nárast sociálnych nerovností, nástup post-faktuálnej a post-politickej (resp. technokratickej) politiky, vzbura chudobných, deklasovaných a marginalizovaných l'udí podporujúcich autoritárstvo radikálnej pravice, návrat (častokrát inštitucionalizovaného) sociálneho „sadizmu“ a odsúdeniahodná rétorika voči ženám, migrantom či menšinám všeobecne.

Dnes je, zdá sa, jasné, že demokracia ako forma organizácie slúži vysoko špecifickým záujmom bohatých, korporácií a elít a stojí v ceste emancipácii a univerzalizácii (Dean 2009). Filozof J. Bíba naznačuje, že liberálna demokracia je $\mathrm{v}$ tomto zmysle len priestorom súperenia elít a obyčajnej 
populácii nezostáva nič iné ako zmierit’ sa s tým, že je z tohto súperenia v skutočnosti vylúčená (Bíba 2014a). Liberálna demokracia ako politická forma zodpovedá skôr Aristotelovej „zmiešanej ústave“, je to „trochu demokracie a vel'a oligarchie“. Ide teda o oligarchickú demokraciu, ktorá sa označuje ako liberálna demokracia. Pokial' našu spoločnost’ nazveme oligarchickou demokraciou, zmení sa myšlienkový terén a uvažovanie o spoločnosti ako takej (Hauser 2012). Podla J. Dean liberálna demokracia privileguje vel'mi bohaté vrstvy spoločnosti. Neprekvapuje preto, že všetky západné „reálne existujúce demokracie“ pri konštituovaní, rozširovaní a obrane neoliberálneho kapitalizmu vylučujú, zneužívajú a utláčajú chudobných a vylúčených (Dean 2009).

Kedysi totiž liberálna demokracia slúžila ako mechanizmus podporujúci emancipáciu (národnostných, sexuálnych, náboženských, jazykových atd') menšín, marginalizovaných a vylúčených, v súčasnosti však získava podobu politického nástroja, ktorý zaist'uje moc privilegovaných a majetných elít. Liberálna demokracia je $\mathrm{v}$ tomto zmysle politickou praxou so špecifickým obsahom; je to akýsi politický manažment súčasného kapitalizmu. Ak je liberálna demokracia politickou formou kapitalizmu (Dean 2014), potom by sme ju mali demaskovat'. Nemožno totiž analyzovat' liberálnu demokraciu bez toho, aby sme sa zaoberali jej kapitalistickým obsahom. Nie je preto prekvapujúce, že čast' všímavých myslitelov tento pojem nahradila výstižnejšou a plastickejšiou terminológiou.

Uved'me len niekol'ko reprezentatívnych príkladov: francúzsky filozof A. Badiou na opis nášho politického systému používa pojem „parlamentný kapitalizmus“ či „tovarová demokracia“; americká filozofka J. Dean „reálne existujúca demokracia“; nemecký intelektuál W. Streeck „trhovo konformná fasádová demokracia“; český filozof M. Hauser „oligarchická demokracia“; francúzsky politológ P. Rosanvallon „demokracie bez kvality pre l'udí bez kvality“; britský sociológ R. Milliband „kapitalistická demokracia“; francúzsky filozof D. Bensaïd „trhová demokracia“ a český filozof B. Horyna „neoliberálna demokracia“.

\section{Neskorý kapitalizmus a jeho univerzalita}

Filozofka W. Brown tvrdí o neoliberálnej tendencii, ktorá v západnej civilizácii pôsobí už niekol'ko desat'ročí, že vedie k individualizácii a je inherentne spätá s internacionalizáciou trhových hodnôt. Kapitalistické hodnoty neoliberalizmu prenikajú do každej sféry l'udského života bez toho, aby si to subjekt vôbec uvedomoval (Brown 2015). Podla P. Masona predstavuje neoliberalizmus vo svojich politických formách akúsi permanentnú danost' (Mason 2017). Kapitalizmus tak dokonalým spôsobom vystihuje 
ontologickú povahu našej epochy. „Neskorý kapitalizmus“ je realitou per se, univerzálnou ontológiou súčasného sveta. „Prakticky neexistuje oblast' individuálneho alebo kolektívneho života, ktorá uniká kapitalistickým vztáahom“ (Laclau, Mouffe 2014, 185). L'udia v liberálnych demokraciách zakúšajú ako ich racionalistické a utilitaristické kritériá užitočnosti a zisku vykoreňujú, ponižujú a zrážajú ich sebavedomie (Mishra 2017).

Ak je pravdou, že súčasný kapitalizmus je ontologicky a geograficky všadeprítomný (Fisher 2010), a zároveň znemožňuje naplnenie radikálnych príslubov demokracie (Leško 2015), potom je kapitalizmus novou vel'kou ontológiou či meta-systémom vzhl'adom na to, že jeho „,...obrovská životaschopnost' spočíva v tom, že tvorí samotný podklad d'alších systémov (vlády parlamentnej demokracie, štátostrany, absolutistickej monarchie, konštitučnej monarchie atd’)“ (Takáč 2012, 47). „To, že sa dnes zdá nemožné predstavit’ si svet bez kapitalizmu, že tlaky na požiadavky produktivity, trhu, investičnej politiky, akumulácie a zamestnania sa zdajú prirodzené a nevyhnutné, je výsledkom triedneho boja, horizotu, v ktorom prebieha, i samotnej formy, ktorú nadobúda" (Dean 2014, 83).

\section{Spät' k demokracii, spät' ku koreňom}

Už sme naznačili, že samotný termín demokracia môže zniet' falošne, a preto sa teraz opät' vynára vo filozofických diskusiách. „Neurčitost' výrazu demokracia vedie k odlišným, často protikladným definíciám“ (Bensaid 2011, 20). Filozof G. Agamben upozorňuje na jeho nejednoznačnost'. Ked’ hovoríme o demokracii, čo tým teda v skutočnosti myslíme? Aký je skutočný obsah tohto vágneho pojmu? Ide vôbec o pojem, ktorý patrí do terminológie politickej filozofie? Demokracia, podl'a neho, môže znamenat' jednu z dvoch diametrálne odlišných vecí. Po prvé, spôsob ako konštituovat' politické telo ( $\mathrm{v}$ tomto prípade sa pohybujeme vo sfére verejného práva), a po druhé, technika vládnutia (v tomto prípade je našim teoretickým horizontom administratívna prax). Inak povedané, demokracia označuje formu, prostredníctvom ktorej je moc legitimizovaná a spôsob, akým je táto moc v praxi vykonávaná. $\mathrm{V}$ súčasnom politicko-filozofickom a politologickom diskurze prevláda druhý význam, pojem demokracia sa teda vo väčšine prípadov používa na to, aby referoval k spôsobu vládnutia. Tieto dve oblasti konceptuality (právno-politické a ekonomicko-manažérske) sa vzájomne prekrývajú od zrodenia politiky a politického myslenia o demokracii v gréckom polis, čo značne znemožňuje ich rozlišovanie (Agamben 2011). 


\section{Politeia ako „zvláštna forma spoločného života“}

Dodajme, že polis sa na scéne objavuje až vtedy, ked' ide o to, čo občania vlastnia spoločne, a ked' sa niekto stará o spôsob, ktorým sú rozdelené formy uplatňovania a kontroly uplatňovania tejto spoločnej moci. Primárnym záujmom politického diskurzu v antickom Grécku nebol jednotlivec a jeho individuálne práva, ale spoločenstvo ako celok (Rancière 2011). „Polis bola organizačnou jednotkou slobodných obyvatelov, podriadených spoločným cielom a záujmom" (Kulašik 2007, 10). Koncepciu ideálnej polis nemožno hodnotit’ paradigmou hodnôt platných v súčasnosti. Je potrebné ju chápat' v dobovom kontexte, v období, v ktorom vznikla (Wollner 2013).

Základný pojem v antickom Grécku referujúci k demokracii - politeia sa prekladá ako republika (do slovenčiny však častokrát aj ako ústava), čo je zároveň názvom pre Platónov dialogický opus magnum. ${ }^{2}$ Pojem republika však nevyčerpáva rozsah svojich významov. Ked' sa však pojem politeia vyskytuje $v$ dielach klasickej filozofie, zvyčajne automaticky nasleduje diskusia o jej troch rôznych formách: monarchia, oligarchia a demokracia, alebo o šiestich variantoch v prípade, že pripočítame tri zodpovedajúce parekbaseis, tri deviantné či perverzné varianty. Prekladatelia stotožňujú pojem politeia niekedy s ústavou (constitution), inokedy s vládou (government). A tak základný politologický koncept odkazujúci k demokracii nás prenáša na terén amfibológie ${ }^{3}$ (Agamben 2011). Fundamentálne pojmy sa v priebehu času stali vágnymi a ambivalentnými a demokracia ako taká sa, zdá sa, „stratila v preklade“. É. Balibar poznamenáva, že grécky pojem politeia je interpretovaný zároveň ako (1.) politické spoločenstvo, (2.) „ústava“ a (3.) forma vládneho režimu (Balibar 2017). Každopádne, politeia, tak ako o nej píše Platón ${ }^{4}$, nie je, ako tvrdí filozof J. Rancière, ústavou, formou, ktorá by sa štiepila na tri známe varianty, na demokratickú, oligarchickú či tyranskú. Politeia je, podla neho, spoločenstvom uskutočňujúcim svoj vlastný princíp interiority vo všetkých prejavoch svojho života (Rancière 2011).

Pojem politeia nám umožňuje pochopit’ samotný pojem demokracia. Teoretik demokracie C. Lefort revitalizoval tento pojem v súvislosti s jeho demokratickým myslením a poňatím politična v kontexte jeho kritiky klasického marxizmu, ktorý redukoval politično výlučne na fenomén nadstavby a neumožňoval mysliet' autonómiu symbolického a ani symbolický charakter politična. Marxizmus, vychádzajúc z triedneho zápasu v skutočnosti opomínal zjavný fakt, že triedne rozdelenie je formou vnútorného

Pozri bližšie Platón (2017).

Pojem pochádza z gramatiky a rétoriky a znamená neurčitost’ významu.

Pozri Platón (2017), Pappas (2005) a Sheppard (2009). 
rozštiepenia celej spoločnosti, ktoré sa vpisuje do spoločenského priestoru, ktorý však musí byt' politicky ustanovený. C. Lefort sa teda vrátil ku klasickej politickej filozofii. Politeia ako klúčový prvok Lefortovej intervencie znamená režim alebo zriadenie. Umožňuje nám mysliet’ politiku a politično ako základ či tvar spoločnosti ako celku, ako „zvláštnu formu spoločného života“. Tento pojem nie je možné redukovat’ na politické a mocenské inštitúcie alebo na ústavu. Je to skôr princíp, ktorý generuje spoločnost' ako takú. Tento princíp formuje spoločnost' a vpisuje sa do všetkých foriem spoločenského života (Bíba 2014b). Prečo má zmysel pozerat' sa na súčasné zriadenie prostredníctvom antickej filozofie a pojmu politeia? Pretože nám uvažovanie o liberálnej demokracii optikou tejto „životnej formy“ či konštitutívneho princípu umožňuje pochopit', že liberálna demokracia je vel'mi obmedzenou formou demokratického zriadenia.

\section{Spät' k Marxovi? Demokracia ako „pravda všetkých štátnych foriem“}

Rovnako ako k Platónovi by sme sa, kritizujúc liberálnu demokraciu, mali vrátit’ aj k Marxovi. Čo však znamená návrat k Marxovi? A v akom zmysle má byt' tento návrat realizovaný? A ku ktorému Marxovi sa máme vrátit?? Aká je dnes relevancia klasického marxizmu? Je Marx skutočne mŕtvy? Filozof É. Balibar konštatuje, že navzdory zlyhaniam Marxa a marxizmu je pre súčasnost’ viac ako kedykol'vek v minulosti nevyhnutné „mysliet’ politiku“ či „otázku politiky“ v rámci Marxových kategórií, ale zároveň tiež proti nim (Balibar 2017). Prečo? Pretože Marx nás učí pochybovat’ o legitimite spoločenských inštitúcií a premýšlat' o ich inherentných rozporoch a dynamike z hladiska záujmu neprivilegovaných tried. „Marx bol presvedčený, že skutočnú demokraciu je možné dosiahnut' iba v socialistickej spoločnosti, kde zanikne triedne protirečenie“ (Lysý 2011, 290). Navyše, mladý „... Marx sa (...) odlišuje od Hegelových autoritárskych politických názorov a naznačuje vlastnú oddanost’ demokracii“ (Peffer 2014, 62). Marx bol presvedčený o tom, že „....demokracia musí byt' rozšírená z politickej do ekonomickej sféry za účelom vytvorenia podmieňujúcich možností zmysluplnej vlády l'udu“ (Leško 2015, 91). Identicky uvažuje analytický marxista R. G. Peffer: „Demokracia nesmie byt’ obmedzená na politickú sféru, ale treba ju uplatňovat' aj v spoločenskej a ekonomickej sfére, predovšetkým na pracovisku“ (Peffer 2014, 390). Marxisti legitímne trvajú na tom, že politická demokracia bez ekonomickej demokracie nie je dostatočná (Segrillo 2012).

Každopádne, Marx používal pojem demokracia až do roku 1845 uznanlivo, neskôr ambivalentne. Rešpektoval tento vágny pojem ako prípustný deskriptor svojho ideálu (Sartori 1993). Neskôr bola pre Marxa vtedajšia 
„demokracia“, jeho slovami diktatúra buržoázie, všeobecným označením pre ekonomické panstvo buržoáznej triedy. Práve toto triedne panstvo bolo určujúce pre konanie elít a štátu ako takého, takže bez ohladu na politickú formu štátu, vyhlásil štát za diktatúru jednej triedy nad druhou. Proti diktatúre buržoázie mala byt' postavená ako jej opak diktatúra proletariátu, ktorá vychádzala zo skúseností Parížskej komúny. Dôležité však je, že Marx jednoznačne nechápal diktatúru buržoázie či diktatúru proletariátu ako politické formy vlády, ale pozeral sa ne v istom zmysle ontologicky ako na spoločensko-ekonomickú podstatu tej-ktorej politickej vlády, ktoré chápal len ako triednu ekonomicko-vlastnícku štruktúru zodpovedajúceho politického poriadku (Znoj 2014).

Marx skutočne v Kritike Hegelovej filozofie práva tvrdí, že všetky štáty majú za horizontom demokraciu ako svoju „pravdu“ ${ }^{5}$, pričom adjektívum „demokratický" v Marxovom myslení (pred tzv. epistemologickým obra$t^{6}{ }^{6}$ ) sa odvoláva na formu organizácie, ktorá ako taká umožňuje pravdu kolektívneho a slobodného sebaurčenia rovných, ktoré je vždy a v každom štáte zablokované. Demokracia je v istej tradícii politickej filozofie, ku ktorej sa hlásil Platón, aj mladý Marx, jednoduchou „pravdou všetkých štátnych foriem". Toto je to, čo majú v istom špecifickom zmysle Marx a Platón spoločné, demokraciu chápu ontologicky. ${ }^{7}$ A tak by sme ju mali chápat’ aj dnes, nie ako techniku vládnutia elitami nad zvyškom spoločnosti. Demokracia nemôže byt' len súborom nejakých procedúr, mala by byt' akýmsi étosom, konštitutívnym princípom či spoločenskou (životnou) formou.

\section{Záver}

Termín demokracia je v dejinách politickej a sociálnej filozofie ambivalentným a vágnym pojmom, ktorý sa používa na deskripciu rôznych záležitostí politického života spoločnosti, ktoré môžu byt' aj v protiklade. Neurčitost' významu pojmu demokracia v relatívne nových podmienkach neskorého kapitalizmu otvára nové otázky, ktoré reflektujú aktuálne trendy a perspektívy spoločenského vývoja. Demokracia ako dynamický spoločenský fenomén preto predstavuje mnohovrstvovú a zložitú tému, ktorá sa v dejinách politického myslenia neustále vynára $v$ politicko-filozofických diskusiách ako jedna z jeho fundamentálnych tém.

Pozri bližšie Marx (1983/1977).

6 Pozri Kužel (2014).

7 Podobne argumentuje aj É. Balibar, ked' konštatuje, že demokracia je v istej tradícii politickej filozofie, ku ktorej sa hlásil aj mladý Marx, jednoduchou „pravdou všetkých štátnych foriem“. Pozri bližšie Balibar (2017). 
V tejto stati hlbšie analyzujeme praktické fungovanie liberálnej demokracie, ktorá sa ako forma reprezentatívnej demokracie etablovala najmä v kapitalistických štátoch západného civilizačného okruhu v predchádzajúcom storočí. V stati sa zaoberáme liberálnou demokraciou v súvislosti s jej previazaním na neskorý kapitalizmus. Liberálnu demokraciu preto po vzore viacerých autorov a autoriek považujeme za politickú formu neskorého kapitalizmu, ktorý je univerzálnym ekonomickým systémom v globálnom meradle, z čoho môžeme vyvodzovat', že je ontologicky a geograficky všadeprítomný, takže nepredstavuje len našu „historickú situáciu“, ale aj náš „horizont myslitel'ného“.

Liberálnu demokraciu v tejto súvislosti podrobujeme kritickej reflexii, ked'že máme dôvod domnievat' sa, že jej praktické fungovanie sa v dôsledku vzostupu neskorého kapitalizmu postupne vzdialilo od etymologického významu tohto pojmu. V tomto kontexte uskutočňujeme dejinný návrat až do čias antickej filozofie (Platón) a prostredníctvom pojmu politeia ukazujeme, že súčasná liberálna demokracia je len vel'mi limitovanou formou demokratického, resp. spoločenského zriadenia. Druhý dejinný návrat v predloženom texte vedie $\mathrm{k}$ Marxovi a $\mathrm{k}$ jeho chápaniu demokracie. $V$ závere sa pokúšame naznačit' paralelu v chápaní demokracie medzi Platónom a Marxom.

\section{Literatúra}

AGAMBEN, G. (2011): Introductory Note on the Concept of Democracy. In: Agamben, G. (ed.): Democracy in What State? New York: Columbia University Press, 1 - 5 .

APPADURAI, A. (2017): Únava z demokracie. In: Geiselberger, H. (ed.): Velký regres. Mezinárodní rozprava o duchovní situaci dneška. Praha: Rybka Publishers, $13-30$.

ARNASON, J. P. (2012): Naše prozatimní krize. In: Pehe, J. (ed.): Krize, nebo konec kapitalismu. Praha: Prostor, 126 - 142.

BALIBAR, É. (2017): Násilí a civilita. Praha: Rybka Publishers.

BARŠA, P. (2012): Rozcestí kapitalismu. In: Pehe, J. (ed.): Krize, nebo konec kapitalismu. Praha: Prostor, 113 - 125.

BENSAID, D. (2011): Permanent Scandal. In: Agamben, G. (ed.): Democracy in What State? New York: Columbia University Press, 16 - 43.

BÍBA, J. (2014a): Za hranice marxismu: radikální demokracie. In: Laclau, E, Mouffe, Ch. Hegemonie a socialistická strategie: za radikálně demokratickou politiku. Praha: Karolinum, 219 - 226.

BÍBA, J. (2014b): Radikální demokracie: výzva antiesencialismu. In: Znoj, M. Bíba, J. - Vargovčíková, J. Demokracie v postliberální konstelaci. Praha: Univerzita Karlova v Praze, Karolinum, 183 - 220. 
BROWN, W. (2015): Undoing the Demos: Neoliberalism's Stealth Revolution. Cambridge, Massachusetts, London: ZONE Books.

DEAN, J. (2009): Democracy and Other Neoliberal Fantasies. Communicative Capitalism and Left Politics. Durham, London: Duke University Press.

DEAN, J. (2014): Slast a politika. Žižkova politická teorie. Praha: Filosofia.

FISHER, M. (2010): Kapitalistický realismus. Praha: Rybka Publishers.

GEISELBERGER, H. (2017): Předmluva. In: Geiselberger, H. (ed.): Velký regres. Mezinárodní rozprava o duchovní situaci dneška. Praha: Rybka Publishers, $5-12$.

HAUSER, M. (2012): Kapitalismus jako zombie neboli Proč žijeme ve světě př́zrakü. Praha: Rybka Publishers.

JAMESON, F. (2009): Postmodernism or The Cultural Logic of Late Capitalism. London, New York: Verso.

KRASTEV, I. (2017): Budoucnost pro většiny. In: Geiselberger, H. (ed.): Velký regres. Mezinárodní rozprava o duchovní situaci dneška. Praha: Rybka Publishers, 89 - 107.

KULAŠIK, P. (2007): Politológia. Hlohovec: Efekt Copy.

KUŽEL, P. (2014): Filosofie Louise Althussera: O filosofii, která chtěla změnit svět. Praha : Filosofia.

LACLAU, E. - MOUFFE, Ch. (2014): Hegemonie a socialistická strategie: za radikálně demokratickou politiku. Praha: Karolinum.

LEŠKO, E. (2015): Marx o sociálnom občianstve: ku kritike depolitizovanej ekonómie. In: Augustín, M. (ed.): Eseje o sociálnom občianstve. Nitra: Univerzita Konštantína filozofa v Nitre, 89 - 101.

LYSÝ, J. (2011): Nepravidelné slovesá modernity. In: Dinuš, P. - Hohoš, L. (eds.): Svet $v$ bode obratu. Systémové alternatívy kapitalizmu: koncepcie, stratégie, utópie. Bratislava: VEDA, Ústav politických vied SAV, 288 - 292.

MARX, K. (1843/1977): Critique of Hegel's Philosophy of Right. In: O'Malley, J. : Marx's Critique of Hegel's Philosophy of Right. Cambridge: Cambridge University Press.

MASON, P. (2017): Překonávání strachu ze svobody. In: Geiselberger, H. (ed.): Velký regres. Mezinárodní rozprava o duchovní situaci dneška. Praha: Rybka Publishers, 121 - 144.

MISHRA, P. (2017): Politika ve věku zloby a temný odkaz osvícenství. In: Geiselberger, H. (ed.): Velký regres. Mezinárodní rozprava o duchovní situaci dneška. Praha: Rybka Publishers, 145 - 164.

PAPPAS, N. (2005): Plato and the Republic. 2nd edition. New York, London: Routledge.

PEFFER, R. G. (2014): Marxizmus, morálka a sociálna spravodlivost'. Bratislava: Vydavatel'stvo spolku slovenských spisovatelov.

PEHE, J. (2012): Úvod. In: Pehe, J. (ed.): Krize, nebo konec kapitalismu. Praha : Prostor, $9-20$.

PLATÓN (2017): Ústava. Praha: OIKOYMENH. 
PORUBJAK, M. 2013. Myslenie archaického Grécka. Všeobecná charakteristika a počiatky gréckeho sociálneho a politického myslenia. In: Novosád, F. Smreková, D. (eds.): Dejiny sociálneho a politického myslenia. Bratislava: Kalligram, 20 - 29.

RANCIÈRE, J. (2011): Neshoda. Politika a filosofie. Praha: Svoboda Servis.

SARTORI, G. (1993): Teória demokracie. Bratislava: ARCHA.

SEGRILLO, A. (2012): Liberalism, Marxism and Democratic Theory Revisited: Proposal of a Joint Index of Political and Economic Democracy. In: Brazilian Political Science Review, 6 (2), 8 - 27.

SEKERÁK, M. (2013): Ekonomická demokracia. Dejiny, teória a prax. Banská Bystrica: Fakulta politických vied a medzinárodných vztahov, Univerzita Mateja Bela.

SHEPPARD, D. J. (2009): Plato's Republic. Edinburgh: Edinburgh University Press.

SLAČÁLEK, O. (2012): Imploze budoucnosti. In: Pehe, J. (ed.): Krize, nebo konec kapitalismu. Praha: Prostor, 93 - 112.

STREECK, W. (2017): Návrat vypuzených jako začátek konce neoliberálního kapitalismu. In: Geiselberger, H. (ed.): Velký regres. Mezinárodní rozprava o duchovní situaci dneška. Praha: Rybka Publishers, 241 - 260.

TAKÁČ, P. (2012): Žižekova kritika liberálnej demokracie. In: Studia Politica Slovaca: časopis pre politické vedy, najnovšie politické dejiny a medzinárodné vztahy, 5 (1), 39 - 48.

TODD, E. (2007): Po impériu. Esej o rozkladu amerického systému. Brno: Computer Press.

WOLLNER, U. (2013): Platón: model zdravej obce. In: Novosád, F. - Smreková, D. (eds.): Dejiny sociálneho a politického myslenia. Bratislava: Kalligram, 72 - 84.

ZNOJ, M. - BÍBA, J. - VARGOVČÍKOVÁ, J. (2014): Úvod. In: Znoj, M. - Bíba, J. Vargovčíková, J. Demokracie v postliberální konstelaci. Praha: Univerzita Karlova v Praze, Karolinum, 7 - 12.

ZNOJ, M. (2014): Neorepublikanismus v polemice s liberalismem a demokracii. In: Znoj, M. - Bíba, J. - Vargovčíková, J. Demokracie v postliberální konstelaci. Praha: Univerzita Karlova v Praze, Karolinum, 27 - 88.

\section{Ing. PhDr. Peter Daubner}

Filozofický ústav Slovenskej akadémie vied

Klemensova 19

81364 Bratislava

Slovenská republika

peter.daubner@nrsr.sk 